\title{
Environmental assessment, CELCO-ARAUCO, and Chile's wetland sanctuary: ethical considerations
}

\author{
Brian M. Marcotte*, Co-Editor-in-Chief \\ Strategic Analysis, Inc., 401 Cumberland Avenue, Suite 1102, Portland, Maine 04101-2875, USA
}

The Carlos Anwandter Sanctuary in southern Chile was designated by Chile on 27 July 1981 as a wetland protected under the United Nations 'Convention on Wetlands of International Importance especially as Waterfowl Habitat' signed in Ramsar, Iran (UNESCO 1971). The Sanctuary receives fresh water from the Rio Cruces and the Rio Calle-Calle that mixes with Pacific seawater in a large estuary at the Bay of Corral. The Sanctuary is home to many species of migratory birds and to waterfowl such as the black-necked swan.

On 18 April 1996, the Comisión Nacional del Medio Ambiente for Chilean Region X (COREMA) acccepted the environmental impact study drafted by the Celulosa Arauco y Constitución (CELCO-ARAUCO) and approved construction of a US $\$ 1$ billion kraftbleached type paper pulp mill on the Rio Cruces near San Jose de la Mariquina (Santiago Times 1996). COREMA's approval was subject to 2 conditions: (1) a company guarantee that hazardous waste would be treated in an environmentally safe fashion (tertiary treatment; Tomat \& Johnson 2005) and, (2) a company promise to develop a monitoring and follow-up plan for its waste products (Santiago Times 1996). At that time, CELCO-ARAUCO assured the regional governor, Rabindranath Quintero, that 'it will have no problem in fulfilling the new requirements' (Santiago Times 1996).

Since the mill began full operations in February 2004 , it has faced repeated complaints from the public concerning noise, noxious odors and water pollution (Tomat \& Johnson 2005) and from eco-tourism businesses associated with the Sanctuary concerned with the loss of black-necked swans and other wildlife (Langman 2005). These complaints resulted in judgments against the mill, and CELCO-ARAUCO was required to pay fines and reparations. The mill was also closed several times for non-compliance with environmental requirements, such as operating in excess of permitted production levels, emissions in excess of approved levels, using coolant waters to dilute effluent and installing an unauthorized second outfall to the Rio Cruces (Tomat \& Johnson 2005).

Mulsow \& Grandjean (2006) note that the environmental impact study presented to the regional environmental regulatory body was drafted by CELCOARAUCO itself. $\mathrm{SO}_{4}$ was the only major chemical compound that the pulp mill was known to release that was not subject to the environmental impact study prior to the mill's operation (Mulsow \& Grandjean 2006; emphasis added). This raises the question of ethical conduct by the Government of Chile and the owners of the pulp mill.

There is a large body of scientific literature on the physics, chemistry and ecological effects of sulphate $\left(\mathrm{SO}_{4}\right)$ and sulfuric acid $\left(\mathrm{H}_{2} \mathrm{SO}_{4}\right)$ discharges from pulp mills. The effluent of the CELCO-ARAUCO mill has been correlated with loss of sub-aquatic plants such as Egeria densa, and the loss of these plants was determined to have caused the death and emigration of black-necked swans that had taken refuge in the Sanctuary (UACH 2004, 2005).

Mulsow \& Grandjean (2006) show that the loss of the plants was caused by $\mathrm{SO}_{4}$ in the mill's effluent. The $\mathrm{SO}_{4}$ caused loss of calcium bicarbonate, $\mathrm{Ca}\left(\mathrm{HCO}_{3}\right)_{2}$, from which the plants extract $\mathrm{CO}_{2}$ for photosynthesis. Without this source of $\mathrm{CO}_{2}$, the plants lost turgor, turned brown and died.

The chemistry of sulfuric acid has been studied since the 16th century. The chemistry of ionic replacement reactions, oxidation-reduction reactions, ion exchanges and the effect of anions like $\mathrm{SO}_{4}$ on calcium bicarbonate buffers has been well understood for over $100 \mathrm{yr}$. The physiological need of $\mathrm{C}_{4}$ plants for carbon dioxide concentrating mechanisms (CCM), and the use 
of calcium bicarbonate by CCM's to enhance $\mathrm{CO}_{2}$ concentrations in their local environment, was established in broad outline almost $30 \mathrm{yr}$ ago. Therefore, the ecosystem effects reported by Mulsow \& Grandjean (2006) were predictable to a reasonable degree of scientific certainty well before the design and construction of the CELCO-ARAUCO pulp mill. The damage to the Carlos Anwandter Sanctuary resulting from the release of pulp mill effluents into the headwaters of the Sanctuary was predictable and preventable either by non-aquatic disposal or treatment of effluent (see below).

There may be short-term responses to the $\mathrm{SO}_{4}$ pollution released by the CELCO-ARAUCO pulp mill. For example, one of the peer reviewers for the paper by Mulsow \& Grandjean (2005) suggested simply adding calcium bicarbonate in the proper proportions to the mill's effluent to neutralize the effects of the sulfates and sulfuric acid on the Sanctuary. A well-designed study of such a short-term response could be done immediately.

Long-term responses, however, may be more profitable for the company and more ecologically responsible. For example, waste from the mill might be used as a resource by other industries and manufacturers, as modeled by McNeil et al. (2005). A survey of Internet resources shows that sulfuric acid is cleaned and recycled in the semiconductor industry. Why not at the CELCO-ARAUCO pulp mill? Sulfuric acid is used as a dehydrating reagent in organic chemical and petrochemical processes involving reactions such as nitration, condensation and dehydration; in the manufacture of fertilizers, glue, dyestuffs and explosives; in the oil refining industry for alkylation and purification of crude oil distillates; in the inorganic chemical industry, notably in the production of $\mathrm{TiO}_{2}$ pigments, hydrochloric acid and hydrofluoric acid; in the metal processing industry, for pickling and de-scaling steel, leaching copper, extracting nickel and in the preparation of electrolytic mats for non-ferrous metal purification and plating; and in leather tanning, for sulfonation in detergent production and for organic sulfonation in the production of pharmaceuticals.

Sulphates like those released by the CELCOARAUCO pulp mill are used in production of fertilizers and fertilizer trace elements, in fermentation, in fire proofing, in manufacture of viscose rayon and in food additives.

With all these possible uses for the chemicals in the effluent of the CELCO-ARAUCO pulp mill, using the Rio Cruces and the Carlos Anwandter Sanctuary as a free corporate sewer lacks imagination and, worse, seems to constitute gross negligence for the operators of a publicly traded company. Could not the CELCOARAUCO mill be 'married' to one or more of these other industrial applications to improve everyone's business activity and profit?

Pulp and paper production is a major source of income for Chile (Neira et al. 2002, World Resources Institute 2005). The pulp mill in question is operated by Celulosa Arauco y Constitución (CELCO), a subsidiary of the Chilean multinational timber company Forestal Arauco, one of the world's 10 largest pulp producers. 99.98\% of Forestal Arauco is owned by Empresas Copec, of which $60.11 \%$ is owned by AntarChile S.A., a company that in 2005 held its corporate meeting at CELCO headquarters, $150 \mathrm{El}$ Golf Avenue, Santiago, Las Condes County, Metropolitan Region, Chile (SEC 2005a). In its United States Securities and Exchange Commission 6-K statement, dated May 2005 (SEC 2005a), AntarChile's President was Alberto Etchegaray Aubry and its voting Directors were Eduardo Navarro Beltrán (Empresas Copec S.A.: 113127452 shares), Manuel E. Besanilla Urrutia (Chilur S.A.: 24746 shares) and José Tomás Guzmán Dumas (AntarChile S.A.: 95 shares). Edmundo Ernst Vallette acted as Secretary. AntarChile is managed by Jorge Andueza Fouque (Forbes 2006).

The 2005 revenue of AntarChile was US $\$ 7.25$ billion, with a net profit margin of $8.19 \%$ (Forbes 2006, SEC 2005a). Further, CELCO-ARAUCO stated in its 25 June 2005 filings with the US Securities and Exchange Commission regarding legal proceedings against the company that, 'We have determined that the suspension of operations at the Valdivia Mill resulted in a loss of sales of approximately US \$1 million per day and a loss of profit of approximately US $\$ 250000$ per day (SEC 2005b) - a profit margin of $25 \%$ for this mill alone.

The owners of the CEOCO-ARAUCO pulp mill and its parent corporation AntarChile could have profited greatly from an imaginative environmental impact study for the sulfate and sulfuric acid wastes their pulp mill produces, but they neglected to conduct such a study. Were the Government and company officials, including the individuals who own and operate the parent corporations, ignorant of the predictable effects of the mill's effluent? Why was the mill operated in blatant disregard of promises made to the regional regulatory officials and governor? Why was the mill operated in violation of production and emission limits? Were the owners grossly negligent? Did the owners not know an unlawful second outflow for their company's wastes had been built? Were their actions simply venal? Did CELCO-ARAUCO have to use the headwaters of the Carlos Anwandter Sanctuary to dump their wastes, given that the mill has a profit margin of $25 \%$ (SEC 2005b) and the parent corporation has a net profit of $8.19 \%$ (Forbes 2006, SEC 2005a) - both profit margins far above current bond 
yields? Are the owners of AntarChile so avaricious that a few tenths of a percent of profit could not be spent in treating or recycling the contents of the mill's effluent to save a Sanctuary?

Plainly, government officials and corporate owners have not acted honorably in this matter, and their unethical conduct has resulted in great damage to a Sanctuary of international importance. The people residing in the affected area have had the quality of their lives and livelihoods degraded.

Science speaks truly if certain rules are followed by regulators, assessors, enforcers and company owners. 1. Science can only disprove null hypotheses. In the case of environmental development, the null hypothesis is, 'The development is not safe for the environment.' Environmental impact assessments attempt to disprove this null hypothesis.

2 . Assessment must be entirely separate from regulation, from enforcement and from business interests. Regulators, enforcers and developers cannot have a say, directly or indirectly, in the choice of assessment provider or in the final decisions concerning the variables to be measured or the methods to be used to conduct the study. These are matters for scientists alone. Accordingly, assessment requires a separate governing body composed of disinterested scientists. If an assessment required by this body is too expensive for the developer, either the government assists because of the expected value of the development or the assessment is not done and the development does not occur. This principle also applies to assessing the safety and effectiveness of, for example, drugs (e.g. Angell 2004, 2006), cosmetics, food additives, seafood harvest areas, fisheries and fisheries technologies.

3. There must be no conflicts of interest-financial, political, or those caused by personal bias either favorable or unfavorable-among the regulators, environmental assessors, or enforcers.

4.Developers, regulators and impact assessors must view development in a comprehensive way. Economic development and environmental protection can be made one through the use of one company's waste as a resource for another or others. Thus, business models may be nested within business models to optimize resources and minimize waste. Developers must conceive of environmental impact assessments as an opportunity to improve their business model as well as protect the environment. They must be open to the possibility of better, perhaps nested, business models.

5. Owners of developments must keep their promises, must honor their oaths and abide by their freely offered word. The owners of Celulosa Arauco y Constitución (CELCO), Forestal Arauco, Empresas
Copec and AntarChile dishonored themselves, their family names and their employees by not operating the mill as they had promised.

6. Because the word of the owners of CELCOARAUCO can no longer be trusted, the company must be forced to operate the mill within permissible production and emission limits by paying the government of Chile to position enforcement agents directly in the mill. Further, employees of CELCOARAUCO must be taught the laws, regulations and special restrictions and/or promises under which the mill operates at the owners' expense. The educated employees then must be called upon publicly to disclose activities at the mill that violate these laws, regulations, restrictions and promises. No retribution against these whistle blowers can be tolerated. Thus, employees must self-regulate and refuse to undertake work that is illegal or contrary to regulation, restrictions or promise.

7.Developers like government regulators and enforcers must think through the predictable consequences of polluting an environment such as the Rio Cruces and the Carlos Anwandter Sanctuary, and those consequences should be proportionate to the damage done and to the economic size of the business. Large companies, especially dishonored ones like CELCO-ARAUCO, must pay more to feel the economic consequences of their wrongdoings. Thus, fines and reparations must not be fixed sums as a matter of law and regulation.

8. Finally, in a time of rapid climate change and rising sea levels, high elevation lands with drainage basins that capture potentially drinkable water, must be understood as held in trust for the future survival, not simple enjoyment, of human kind. No landowner should be allowed to diminish the future of human survival by polluting or despoiling such lands and drainage basins.

Had these simple principles been followed in the present case, a better and more profitable future might have been imagined and implemented for the paper industry and the residents of San Jose de la Mariquina, Valdivia and their environs.

\section{LITERATURE CITED}

Angell M (2004) The truth about the drug companies. Random House, New York

Angell M (2006) Your dangerous drugstore. The New York Review of Books 53 (10) Available at: www.nybooks.com/ articles/19055

Forbes (2006) Forbes 2000: AntarChile S. A. Available at: www.forbes.com/lists/2006/18/2044619.html

Langman J (2005) Fighting for Chile's swans. Available at: www.chiletravel.com/chile/publish/article_434.html

McNeill J, Grant RG, van der Meulen A (2005) Integrated biosystems for resource conservation in rural industries: 
an Australian experience. Ethics in Science and Environmental Politics 2005:23-31

Mulsow S, Grandjean M (2006) Incompatibility of sulphate compounds and soluble bicarbonate salts in the Rio Cruces waters: an answer to the disappearance of Egeria densa and black-necked swans in a RAMSAR sanctuary. Ethics in Science and Environmental Politics 2006:5-11

Neira E, Vescheure H, Revenga C (2002) Chile's frontier forests: conserving a global treasure. Available at: http:// pdf.wri.org/gfw_chile_full.pdf

Santiago Times (1996) Cellulose project approved by regional authorities. Available at: http://ssdc.ucsd.edu/news/chip/ h96/chip.19960418.html\#a5

SEC (2005a) Arauco and Constitution Pulp Company 6K filing 17 May 2005. Available at: www.secinfo.com/ d14D5a.z3av6.htm

SEC (2005b) Arauco and Constitution Pulp Company legal proceedings disclosure. Available at: http:// sec.edgar-online.com/2005/06/29/0001193125-05-134951/ Section14.asp Retrieved 20 May 2006
Tomat D, Johnson S (2005) Pulp mill study program. Report 2. Report on visit to Brazil and Chile. Available at: www.pulpmill.tas.gov.au/infopapers/Study $\% 20$ Program \%20Report.pdf

Universidad Austral de Chile (UACH) (2004) Primer Informe sobre 'Estudio sobre origen de mortalidades y disminucion de aves acuaticas en el santuario de la naturaleza Carlos Anwandter, en la Provincia de Valdivia'

Universidad Austral de Chile (UACH) (2005) Segundo Informe sobre 'Estudio sobre origen de mortalidades y disminucion de aves acuaticas en el santuario de la naturaleza Carlos Anwandter, en la Provincia de Valdivia'

UNESCO (United Nations Educational, Scientific and Cultural Organization) (1971) Convention on Wetlands of International Importance Especially as Waterfowl Habitat. Available at: www.ramsar.org/key_conv_e.htm

World Resources Institute (2005) Chile's frontier forests: distribution of different land uses and native forests in Chile. Available at: http://earthtrends.wri.org/maps_spatial/ maps_detail_static.php?map_select $=451 \&$ theme $=9$ 